\title{
Mūsīqī dar 'așr-e mašrūte. Pažūhešī dar honar-e 'așr-e mašrūṭiyyat (ketāb-e dovvom). Tehrān, Mehrnāmag, 1384/2005, 469 p., index.
}

\section{Poupak Rafii Nejad}

\section{(2) OpenEdition}

1 Journals

\section{Édition électronique}

URL : http://journals.openedition.org/abstractairanica/7622

DOI : 10.4000/abstractairanica.7622

ISSN : 1961-960X

\section{Éditeur :}

CNRS (UMR 7528 Mondes iraniens et indiens), Éditions de l'IFRI

\section{Édition imprimée}

Date de publication : 15 mai 2007

ISSN : 0240-8910

\section{Référence électronique}

Poupak Rafii Nejad, « Mūsīqī dar 'așr-e mašrūțe. Pažūhešĩ dar honar-e 'așr-e mašrūtiyyat (ketāb-e dovvom). Tehrān, Mehrnāmag, 1384/2005, 469 p., index. », Abstracta Iranica [En ligne], Volume 28 | 2007, document 517, mis en ligne le 18 septembre 2007, consulté le 25 septembre 2020. URL : http:// journals.openedition.org/abstractairanica/7622 ; DOI : https://doi.org/10.4000/abstractairanica.7622

Ce document a été généré automatiquement le 25 septembre 2020.

Tous droits réservés 


\title{
Mūsīqī dar 'aṣr-e mašrūțe. Pažūhešī dar honar-e 'așr-e mašrūțiyyat (ketāb-e dovvom). Tehrān, Mehrnāmag, 1384/2005, 469 p., index.
}

\author{
Poupak Rafii Nejad
}

Deuxième volume d'une série d'études sur l'art de mašrūtiyyat, consacré à la musique. Cet ouvrage comprend deux parties. La première est constituée par l'introduction de l'A., ses explications sur le choix des documents, leur structuration et leur analyse avec une conclusion sur la dimension culturelle de la révolution constitutionnelle. La deuxième partie concerne la publication des données: compilation de documents d'archives constituée essentiellement d'annonces parues dans les journaux d'époque portant sur les activités musicales (clubs, associations ou écoles de musique, cours particuliers, concerts, opérettes, orchestres, achat et vente d'instruments de musiques, de gramophones et de disques, etc.). Des documents officiels (rapports, lettres, directives des autorités religieuses ou politiques) s'ajoutent ici et là aux annonces de journaux. Ces documents couvrent la période de mašrūtịyyat (1285h.-1304h.) qui semble représenter un tournant, selon l'A., dans l'évolution de la musique iranienne. Viennent compléter ce travail de documentaliste, une série de notes ou d'articles sur la musique, parus également dans les journaux de l'époque. Parmi leurs auteurs on peut citer Malek ol-šo'arā-ye Bahār ou Șabā. À la fin de l'ouvrage se trouve un index de personnalités et dignitaires (rejāl), un index dit général ('omūmī) et un index des noms de lieux, suivis de la reproduction de quelques-uns des documents cités dans l'ouvrage. Aucune bibliographie à la fin ; uniquement des références citées en notes de bas de page. 
INDEX

Thèmes : 17.1.Musique

\section{AUTEURS}

POUPAK RAFII NEJAD

CNRS / Mondes iranien et indien - Paris 